University of Nebraska - Lincoln

DigitalCommons@University of Nebraska - Lincoln

USDA National Wildlife Research Center - Staff Publications
U.S. Department of Agriculture: Animal and Plant Health Inspection Service

2014

\title{
Prevalence and diversity of Babesia, Hepatozoon, Ehrlichia, and Bartonella in wild and domestic carnivores from Zambia, Africa
}

Brianna M. Williams

University of Georgia

Are Berentsen

USDA/APHIS/WS/National Wildlife Research Center

Barbara C. Shock

University of Georgia

Maria Teixiera

University of Georgia

Michael R. Dunbar

USDA/APHIS/WS/National Wildlife Research Center

See next page for additional authors

Follow this and additional works at: https://digitalcommons.unl.edu/icwdm_usdanwrc

Part of the Life Sciences Commons

Williams, Brianna M.; Berentsen, Are; Shock, Barbara C.; Teixiera, Maria; Dunbar, Michael R.; Becker, Matthew S.; and Yabsley, Michael J., "Prevalence and diversity of Babesia, Hepatozoon, Ehrlichia, and Bartonella in wild and domestic carnivores from Zambia, Africa" (2014). USDA National Wildlife Research Center - Staff Publications. 1595.

https://digitalcommons.unl.edu/icwdm_usdanwrc/1595

This Article is brought to you for free and open access by the U.S. Department of Agriculture: Animal and Plant Health Inspection Service at DigitalCommons@University of Nebraska - Lincoln. It has been accepted for inclusion in USDA National Wildlife Research Center - Staff Publications by an authorized administrator of DigitalCommons@University of Nebraska - Lincoln. 


\section{Authors}

Brianna M. Williams, Are Berentsen, Barbara C. Shock, Maria Teixiera, Michael R. Dunbar, Matthew S.

Becker, and Michael J. Yabsley 


\title{
Prevalence and diversity of Babesia, Hepatozoon, Ehrlichia, and Bartonella in wild and domestic carnivores from Zambia, Africa
}

\author{
Brianna M. Williams • Are Berentsen • \\ Barbara C. Shock • Maria Teixiera • Michael R. Dunbar • \\ Matthew S. Becker • Michael J. Yabsley
}

Received: 30 August 2013 / Accepted: 27 November 2013 / Published online: 21 December 2013

(C) Springer-Verlag Berlin Heidelberg 2013

\begin{abstract}
A molecular survey was conducted for several hemoparasites of domestic dogs and three species of wild carnivores from two sites in Zambia. Three Babesia spp. were detected including Babesia felis and Babesia leo in lions (Panthera leo) and a Babesia sp. (similar to Babesia lengau) in spotted hyenas (Crocuta crocuta) and a single lion. All wild dogs (Lycaon pictus) and domestic dogs were negative for Babesia. High prevalences for Hepatozoon were noted in all three wild carnivores (38-61\%) and in domestic dogs (13\%). Significantly higher prevalences were noted in hyenas and wild dogs compared with domestic dogs and lions. All carnivores were PCR negative for Ehrlichia canis, Ehrlichia ewingii, and Bartonella spp. Overall, high prevalences and diversity of Babesia and Hepatozoon were noted in wild carnivores from Zambia. This study is the first molecular characterization of Babesia from any hyena species and is
\end{abstract}

B. M. Williams $\cdot$ B. C. Shock $\cdot$ M. J. Yabsley

Warnell School of Forestry and Natural Resources, University of Georgia, 180 E Green Street, Athens, GA 30602, USA

B. M. Williams $•$ B. C. Shock $\cdot$ M. Teixiera $\cdot$ M. J. Yabsley $(\bowtie)$ Southeastern Cooperative Wildlife Disease Study, College of

Veterinary Medicine, University of Georgia, 589 D. W. Brooks Dr.,

Wildlife Health Building, Athens, GA 30602, USA

e-mail: myabsley@uga.edu

A. Berentsen • M. R. Dunbar

USDA/APHIS/WS/National Wildlife Research Center,

4101 LaPorte Avenue, Fort Collins, CO 80521, USA

M. Teixiera

Federal University of Mato Grosso do Sul, Campo Grande, MS 79070-900, Brazil

\section{S. Becker}

Zambian Carnivore Programme, Zambia and Department of Ecology, Montana State University, PO Box 80, Mfuwe,

Eastern Province, Bozeman, MT 59717, USA the first report of a Babesia sp. closely related to B. lengau, a parasite previously only reported from cheetahs (Acinonyx jubatus), in lions and hyenas. Although usually benign in wild carnivores, these hemoparasites can be pathogenic under certain circumstances. Importantly, data on vectors for these parasites are lacking, so studies are needed to identify vectors as well as determine transmission routes, infection dynamics, and host specificity of these hemoparasites in wildlife in Africa and also the risk of transmission between domestic animals and wildlife.

\section{Introduction}

In many parts of Africa, large predator populations have undergone severe declines, primarily due to anthropogenic factors; however, disease issues have also caused local declines and concern for species conservation (Ray et al. 2005; Munson et al. 2008). Three species included in this study, the African wild dog (Lycaon pictus), the African lion (Panthera leo), and the spotted hyena (Crocuta crocuta), are listed as endangered or threatened in all or parts of their ranges. An understanding of the natural history of pathogens in these carnivores is complicated by their threatened/endangered status, changes in their ecosystems, and interactions with domesticated animals (Woodroffe et al. 2012).

Infections with hemoparasites in the genera Babesia and Hepatozoon and vector-borne bacteria in the genera Ehrlichia and Bartonella are common in many wildlife species (Breitschwerdt and Kordick 2000; Penzhorn 2006; Rar and Golovijova 2011). Although these infections are typically asymptomatic, they can be pathogenic under certain circumstances (e.g., unnatural hosts, stress due to captivity, habitat degradation or climate fluctuation or immunosuppression) (Penzhorn 2006; Munson et al. 2008; East et al. 2008). For 
example, Babesia and canine distemper virus coinfections have caused severe mortality in African lions (Munson et al. 2008) and Hepatozoon, which normally causes asymptomatic infections in carnivores, is suspected to have caused mortality in juvenile spotted hyenas in Tanzania (East et al. 2008).

Hemoparasite research in carnivores in Zambia is limited, and data on the natural history of wild carnivores is also lacking. In Lusaka, the capital city, a low percentage of domestic dogs (Canis familiaris) were positive for Babesia (Nalubamba et al. 2011) and a dog recently exported from Zambia was infected with Ehrlichia canis (Baba et al. 2012). Related work on wild carnivores in Zambia indicates that infection with gastrointestinal parasites is common (Berentsen et al. 2012). To better understand the prevalence and diversity of vector-borne hemoparasites in Zambian carnivores, we conducted a molecular survey for Babesia spp., Hepatozoon spp., Ehrlichia canis, Ehrlichia ewingii, and Bartonella spp. in domestic dogs, lions, spotted hyenas, and African wild dogs from two regions in Zambia, Africa.

\section{Materials and methods}

Study Area

Samples were collected in a $3,000-\mathrm{km}^{2}$ area of east-central South Luangwa National Park (SL) and in Liuwa Plain National Park (LP) which are located in Zambia's Eastern and Western Provinces, respectively (Fig. 1). South Luangwa National Park is a mosaic of deciduous forest, grasslands, and woodlands (Astle et al. 1969; White 1983; Astle 1988). The Luangwa River forms the eastern border for most of the park. Liuwa Plain National Park is approximately $3,500 \mathrm{~km}^{2}$ of grasslands, floodplains, and woodlands and is home to the second largest wildebeest (Connochaetes taurinus) migration on the continent. The park is recovering from decades of poaching which resulted in a reduction of prey species and, consequently predators. New management of LP has resulted in increased game populations in recent years, and a high population of spotted hyenas. Other

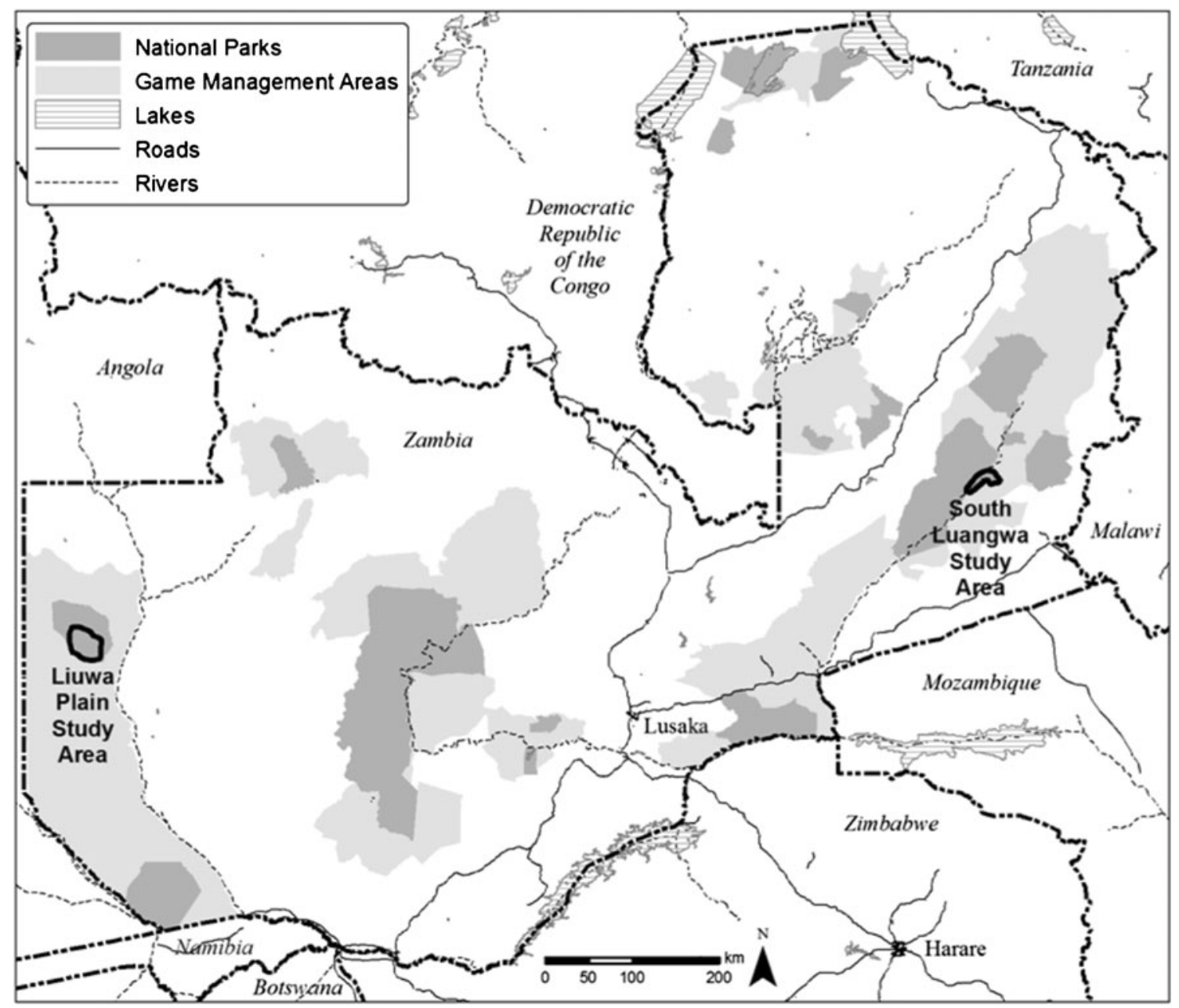

Fig. 1 Location of Liuwa Plains National Park and South Luangwa National Park, Zambia (adapted from Berentsen et al. 2013) 
predators are returning, including lions, African wild dogs, and cheetahs (Acinonyx jubatus).

Sample collection

Samples were collected from May 2009-August 2011. Domestic dogs were physically restrained and blood samples obtained by venipuncture of the cephalic vein. Samples from wild carnivores were collected during chemical immobilization during concurrent studies of carnivore ecology or during removal of poaching snares. Wild carnivores were immobilized with a mixture of zoletil and medetomidine, reversed with atipamezole (Kock et al. 2006) and blood samples were obtained via venipuncture of the jugular, cephalic, or saphenous vein. Thick blood smears were immediately prepared in the field, fixed in ethanol, and maintained at room temperature until testing. All immobilization procedures followed animal welfare standards and protocols required by the Zambia Department of Veterinary and Livestock Development and the Zambia Wildlife Authority. All procedures were approved by the National Wildlife Research Center's Institutional Animal Care and Use Committee under Protocol QA-1725.

\section{Molecular Analysis}

Genomic DNA was extracted from thick blood smears using the Qiagen DNA Purification Kit (Germantown, MD) following the manufacturer's protocol except that the dried blood was scraped from the slide after a 10-min incubation with proteinase K and ATL buffer. For detection of Babesia and Hepatozoon infections, a PCR protocol targeting a $~ 600$-bp region of the 18S rRNA gene was conducted using primers KIM18SF (5'-GAAATTAGAGTGTTTC) and KIMR2 (5'ACCCTATTTAGCAGGTTAAG). For each PCR reaction, $5 \mu \mathrm{l}$ of DNA was added to $20 \mu \mathrm{l}$ of a master mix containing $11 \mu \mathrm{L}$ of water, $2.5 \mu \mathrm{L}$ of $25 \mu \mathrm{M} \mathrm{MgCl}_{2}, 5 \mu \mathrm{L}$ of $5 \mathrm{X} \mathrm{GoTaq}{ }^{\circledR}$ Flexi Buffer, $0.25 \mu \mathrm{L}$ of $0.2 \mathrm{mM}$ each dNTP (Promega), $0.5 \mu \mathrm{L}$ of each primer $(50 \mu \mathrm{M})$, and $0.25 \mu \mathrm{L}$ GoTaq ${ }^{\circledR}$ Flexi DNA Polymerase (Promega). The cycling parameters were $94{ }^{\circ} \mathrm{C}$ for $2 \mathrm{~min}$ followed by 40 cycles of $94^{\circ} \mathrm{C}$ for $45 \mathrm{~s}, 45^{\circ} \mathrm{C}$ for $1 \mathrm{~min}$, and $72^{\circ} \mathrm{C}$ for $1 \mathrm{~min}$. For additional characterization and to confirm results of the $18 \mathrm{~S}$ rRNA gene sequencing for Babesia spp., a PCR protocol that amplifies the entire internal transcribed spacer (ITS)-2 rRNA region was conducted on selected samples (Shock et al. 2012). For two samples that were positive for a Babesia species similar to Babesia lengau, the near full-length 18S rRNA was amplified as described (Yabsley et al. 2009).

Nested PCRs specific for the 16S rNA gene of $E$. canis and E. ewingii were conducted as described using primers ECC and ECB in a primary PCR (Dawson et al. 1994) followed by two separate nested PCRs using either primers ECA and HE3 for $E$. canis (Wen et al. 1997) or primers EE72 and HE3 for E. ewingii (Anderson et al. 1992a; b). To detect Bartonella spp., a PCR protocol that amplifies the ITS- 1 rRNA region was conducted (Roux et al. 2000). Amplified products were separated in $2 \%$ agarose gels, stained with ethidium bromide, and visualized with UV light. A negative water control was included in each set of DNA extraction, and a different water control was included in each set of primary and secondary PCR reactions. Appropriate positive controls (i.e., DNA from a culture of $E$. chaffeensis, dog blood positive for E. ewingii, feline blood positive for Bartonella, and a puma (Puma concolor) blood sample positive for a Babesia sp. distinct from any detected in this study) were included in each batch of PCR reactions.

To confirm identity, all 18S rRNA gene amplicons and representative ITS-2 amplicons were purified with a Qiagen gel extraction kit (Germantown, MD) and bi-directionally sequenced at the Georgia Genomics Facility (Athens, GA). Chromatograms were analyzed with Sequencher 5.0 (Gene Codes, MI). Sequences of $18 \mathrm{~S}$ rRNA were aligned with those from related organisms obtained from GenBank using a basic local alignment search tool (BLAST) search (National Center for Biotechnology Information, Bethesda, MD) (Altschul et al. 1990). Phylogenetic analyses were conducted using Molecular Evolutionary Genetics Analysis (MEGA) using the neighbor-joining and minimum evolution analyses with the Kimura 2-parameter model and maximum parsimony using a close-neighbor-interchange search. Bootstrap analyses (1,000 replicates) were used to assess branch reliability. Sequences from this study have been deposited in the GenBank database (KF270642-KF270678, KF510019KF510025).

\section{Data Analysis}

Fischer's exact test was performed to detect differences in prevalence between species and location $(p<0.05$ was considered significant).

\section{Results}

Babesia infections were noted in two wild carnivore species, lions and hyenas, with similar prevalences noted for each (Table 1). Similarly, no differences in Babesia prevalence were noted between the two sites for either species. Based on sequence analysis of one or both gene targets, at least three Babesia spp. were detected including Babesia felis and Babesia leo in lions and a Babesia sp. (similar to Babesia lengau) in the six positive spotted hyenas and a single lion. The near full-length sequence (1,361 bp) of the Babesia from the hyenas was $99 \%$ similar to $B$. lengau from cheetahs (Fig. 2, Bosman et al. 2010). Other closely related species 
Table 1 PCR results for Babesia and Hepatozoon of lions (Panthera leo), spotted hyenas (Crocuta crocuta), wild dog (Lycaon pictus), and domestic dogs collected from Liuwana Plains National Park (LP) and South Luangwa National Park (SL), Zambia

\begin{tabular}{|c|c|c|c|c|}
\hline \multirow[t]{2}{*}{ Site } & \multirow[t]{2}{*}{ Species } & \multirow[t]{2}{*}{ Number } & \multicolumn{2}{|c|}{ No. positive (\%) } \\
\hline & & & Babesia & Hepatazoon \\
\hline \multirow[t]{4}{*}{ Liuwa Plain National Park (LP) } & Domestic dog & 2 & 0 & 0 \\
\hline & Lion & 1 & 0 & $1(100)$ \\
\hline & Spotted hyena & 9 & $3(33)$ & $5(56)$ \\
\hline & Wild dog & 4 & 0 & $2(50)$ \\
\hline \multirow[t]{4}{*}{ South Luangwa National Park (SL) } & Domestic dog & 6 & 0 & $1(20)$ \\
\hline & Lion & 23 & $6(26)$ & $13(57)$ \\
\hline & Spotted hyena & 10 & $3(30)$ & $2(20)$ \\
\hline & Wild dog & 7 & 0 & $4(57)$ \\
\hline \multirow[t]{4}{*}{ Both sites } & Domestic dog & 8 & 0 & $1(13)^{\mathrm{a}}$ \\
\hline & Lion & 24 & $6(25)$ & $9(38)^{\mathrm{a}}$ \\
\hline & Spotted hyena & 19 & $6(32)$ & $11(61)^{b}$ \\
\hline & Wild dog & 11 & 0 & $6(55)^{\mathrm{b}}$ \\
\hline
\end{tabular}

Different letters indicate a significant difference $(p<0.05)$ in prevalence between species were noted and some sequences were highly similar to Hepatozoon canis or Hepatozoon felis (KF270642-4, KF270646, KF270651, KF270654, KF270658-60, KF270663-5, KF270667-9, and KF270673). Hepatozoon canis-like sequences were detected in hyena, lions, and wild dogs whereas $H$. felis-like sequences were detected in lions and hyenas. Coinfections with Babesia and Hepatozoon were noted in one lion at the SL site. All carnivores were PCR negative for E. canis, E. ewingii, and Bartonella spp.

\section{Discussion}

In the current study, at least three species of Babesia in two species of wild carnivores from Zambia were detected. Previous studies have reported Babesia in several species of African carnivores including domestic dogs, domestic cats, lions, cheetahs, wild cats (Felis silvestris), caracal (Felis caracal), and hyenas (Van den Berge 1937; Barnett and Brocklesby 1968; Collett 2000; Penzhorn et al. 2001; Bosman et al. 2007; 2010; Munson et al. 2008; Bosman
Fig. 2 Phylogenetic analysis of near full-length 18S rRNA gene sequence of a Babesia lengaulike sp. from spotted hyenas from Zambia

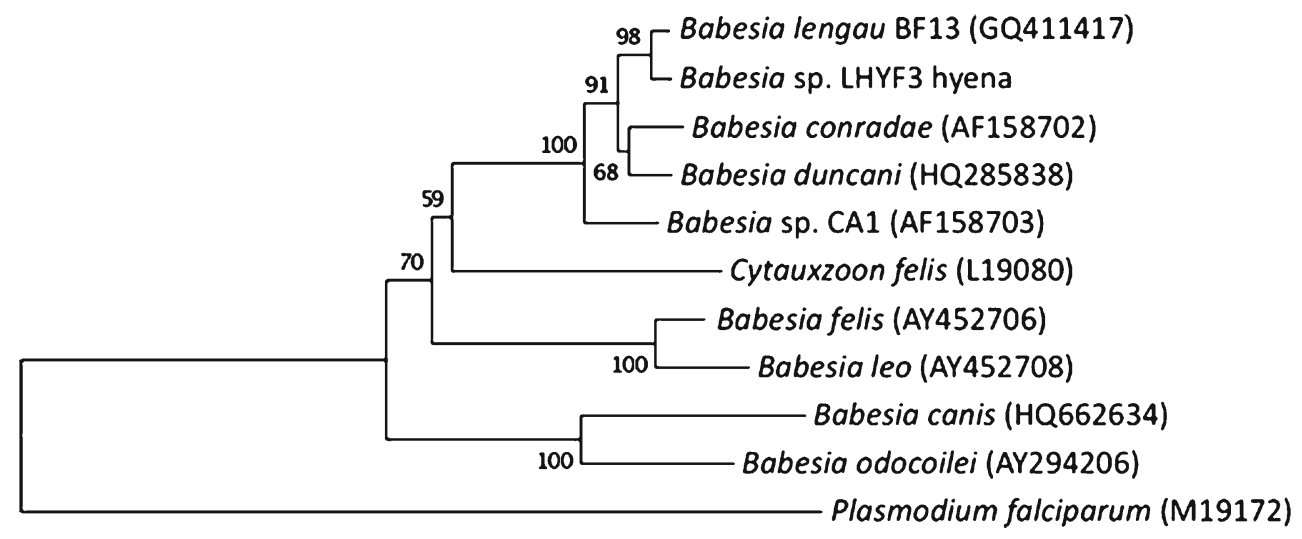


et al. 2013). Although none of the domestic dogs in our study were positive for Babesia, a low prevalence has been reported in the capital of Zambia and infection is common in domestic dogs ( $10 \%$ prevalence) in South Africa (Collett 2000; Nalubamba et al. 2011). We found no evidence of Babesia in wild dogs; however, $B$. canis rossi has been reported from free-ranging wild dogs from South Africa and uncharacterized Babesia have been detected from wild dogs from South Africa and Tanzania (Matija et al. 2008; Peirce et al. 1995; Van Heerden et al. 1995). In addition, wild dogs are experimentally susceptible (Matija et al. 2008; Peirce et al. 1995; Van Heerden et al. 1995) and a fatal case in a captive wild dog has been reported from South Africa (Colly and Nesbit 1992). Our failure to detect Babesia in wild dogs could be because sampled animals may have little contact with areas that contain domestic dogs or vectors or because the prevalence is too low to detect with our sample sizes. There may also be geographic differences as Prager et al. (2012) sampled 264 wild dogs from five populations in southern Africa from 1998 to 2009 and did not detect any Babesia infections.

To our knowledge, this is the first report of Babesia in lions from Zambia although lions are commonly infected with Babesia spp. in other southern African counties (e.g., South Africa, Swaziland) (Lopez-Rebollar et al. 1999; Penzhorn et al. 2001; Bosman et al. 2007; Munson et al. 2008; Githaka et al. 2012). In the current study, lions were infected with three Babesia species; B. leo and B. felis were the two most common, and both of these Babesia spp. have been reported from a wide range of African felids, including lions (Bosman et al. 2007). Domestic cats and leopards (Panthera pardus ) are experimentally susceptible to both of these Babesia spp. (Penzhorn et al. 2001; Lopez-Rebollar et al. 1999). Previous work on free-ranging lions indicated that coinfections with B. leo and B. felis were common (Bosman et al. 2007). The failure to detect Babesia spp. coinfections in the current study could be related to the testing method (direct sequencing of PCR products) since previous studies have used reverse line blot hybridization $(\mathrm{RLBH})$, a more sensitive assay for detecting mixed infections.

Sequence analysis of our products also detected a single lion infected with a Babesia sp. related to B. lengau which is the first report of this parasite species in lions. Interestingly, use of RLBH with genus and species-specific probes in a previous study showed that an unknown species of Babesia was detected in lions from southern Africa (Bosman et al. 2007). Because this species was not characterized by sequence analysis, its relationship to the Babesia sp. identified in this study is not clear. Additional sequence analysis of Babesia samples from lions in other countries is necessary to determine if the Babesia species detected in the current study is widely distributed. Recently, B. lengau was reported in two cases of severe cerebral and hemolytic babesiosis in two domestic cats in South Africa (Bosman et al. 2013).
The only previous reports of Babesia from the Family Hyaenidae include Babesia alberti described from the spotted hyena (Van den Berge 1937) and an unnamed Babesia sp. from the aardwolf (Proteles cristata; Peirce et al. 2001). This study is the first molecular characterization of Babesia from any species of hyena, and is the first report of a Babesia sp. related to $B$. lengau. Although $B$. lengau has only been detected in cheetahs, a Babesia recently detected from clinically ill domestic sheep in Greece was reported to be $99 \%$ similar to B. lengau (Giadinis et al. 2012); however the sequence of the Greece sheep Babesia was not available in Genbank for comparison with our sequences (as of 6 November 2013). The host range of Babesia sp. related to $B$. lengau now includes three species of African carnivores and possibly domestic sheep. In the current study, ITS-2 sequences from two hyenas confirmed the close relationship of the hyena Babesia with B. lengau. However, the significance of two distinct ITS-2 sequences among the B. lengaulike species detected in this study is unknown. It is unknown if the Babesia sp. detected in the current study is the same as $B$. alberti because thin blood smears were not available for morphological analysis and genetic characterization of $B$. alberti has not been conducted.

A high prevalence of Hepatozoon detected in all species tested was not unexpected because Hepatazoon infections have been reported from numerous free-ranging African carnivores including lions, spotted hyenas, hyenas, wild dogs, and domestic dogs (Brocklesby 1971; McCully et al. 1975; Averbeck et al. 1990; Dubey and Bwangamoi 1994; Peirce et al. 1995; Van Heerden et al. 1995; East et al. 2008). Most infections have been identified by examination of blood smears and were classified as $H$. canis, a cosmopolitan parasite of canids; however, recent genetic characterization has revealed that numerous variants, subspecies, or cryptic species of $H$. canis exist worldwide (East et al. 2008; Gabrielli et al. 2010; Starkey et al. 2013). In wild canids, Hepatozoon infections are typically subclinical (McCully et al. 1975), but a non-H. canis species of Hepatozoon was reported to cause clinical disease in spotted hyenas in Tanzania (East et al. 2008). Based on the gene target used in the current study, several Hepatozoon sequences were detected, but some samples were very similar to $H$. canis and $H$. felis . A recent PCR study on wild felids and canids in India detected $H$. felis only in felids (lions, tigers, and leopards) and $H$. canis only in canids (domestic dogs and Indian wild dogs) (Pawar et al. 2012); however, these parasites are not considered to be specific to the suborders of the Carnivora and $H$. canis and $H$. felis have been reported in both canids and felids (Rubini et al. 2006; Jittapalapong et al. 2006; Baneth et al. 2013). Similarly, in the current study, $H$. canis-like sequences were detected in felids (lions) and hyena and $H$. felis-like sequences were detected in hyenas.

No evidence of E. canis, E. ewingii, or Bartonella DNA was detected in any wild carnivores or in domestic dogs. 
Among domestic dogs, E. canis has been reported throughout sub-Saharan African including Sudan, Cameroon, Gabon, Kenya, and South Africa and in a dog that had recently been imported to the Netherlands from Zambia (Kaminjolo et al. 1976; Ndip et al. 2005; Matjila et al. 2008; Baba et al. 2012). Using PCR, E. ewingii has been detected in domestic dogs from Cameroon (Ndip et al. 2005). Based on serologic testing, antibodies reactive to $E$. canis have been reported in domestic dogs from Maasai Mara, Kenya, but not in sympatric African wild dogs (Alexander et al. 1993). Three other studies detected antibodies in domestic cats, domestic dogs, jackals, and Africa wild dogs in Kenya and South Africa (Alexander et al. 1994; Matthewman et al. 1996; Flacke et al. 2010; Woodroffe et al. 2012). Although not confirmed, a decline in wild dog numbers in South Africa was suspected to have been caused by ehrlichiosis (Neitz and Thomas 1938). A single study on 21 lions in Botswana failed to detect antibodies to E. canis (Ramsauer et al. 2007). Despite reports of antibodies in some wildlife species, no Ehrlichia species has been detected in wild carnivores in Africa by PCR, similar to our negative PCR data (Matjila et al. 2008). Unfortunately, serum samples were not available for serologic testing; however, future studies should incorporate both molecular and serologic testing to identify the species of Ehrlichia responsible for antibody responses previously detected in domestic and wild canids. For example, an Ehrlichia ruminantium-like sp. has been detected by PCR in domestic dogs in South Africa (Allsopp and Allsopp 2001) and the serologic cross-reactivity of E. canis and E. ruminantium has been demonstrated (Kelly et al. 1994). Previous studies have identified Bartonella henselae in lions, but both serologic and molecular-based prevalence rates are low (Molia et al. 2004; Pretorius et al. 2004). The lack of Bartonella PCR positives in the current study is not unexpected because culture enrichment followed by PCR is the most sensitive method for detection (Duncan et al. 2007).

The findings of the current study indicate that there is considerable variation in the prevalence of Babesia and Hepatozoon among the tested carnivore species. The reason for differences in Babesia and Hepatozoon prevalence between hosts is unknown, primarily because very little is known about the life cycles, transmission routes, host specificity, or pathogenic potential of these carnivore parasites. Asymptomatic infections with Babesia and Hepatozoon wild African carnivores are common (McCully et al. 1975; Averbeck et al. 1990; Van Heerden et al. 1995; LopezRebollar et al. 1999; Penzhorn et al. 2001; Penzhorn 2006; Bosman et al. 2007; Bosman et al. 2010; Githaka et al. 2012); however, there are reports of disease in hyenas with Hepatozoon (East et al. 2008) and Babesia can cause disease in lions if parasites are present in high numbers or if hosts are immunosuppressed or stressed (Penzhorn 2006; Munson et al. 2008). Finally, a combination of morphological and molecular characterization of these parasites would greatly enhance our ability to compare contemporary studies with historical studies. Future studies should focus on understanding vectors, transmission routes, infection dynamics, parasite diversity, and host specificity of these hemoparasites in African wildlife and the risk of transmission between domestic animals and wildlife.

Acknowledgments Funding for SLNP and LP work was provided from Worldwide Fund for Nature-Netherlands, African Parks Network, Painted Dog Conservation Inc., and the Royal Society for Prevention of Cruelty to Animals. Additional support was provided to SCWDS by the Federal Aid to Wildlife Restoration Act (50 Stat. 917) and through sponsorship from member fish and wildlife agencies. The authors thank the Zambia Wildlife Authority and Department of Veterinary and Livestock Development for their permission and collaboration in this research and C. Mulipukwa for field assistance.

Conflict of interest The authors have no knowledge of a conflict of interest.

\section{References}

Alexander KA, Conrad PA, Gardner IA, Parish C, Appel M, Levy MG, Lerche N, Kat P (1993) Serologic survey for selected microbial pathogens in African wild dogs (Lycaon pictus) and sympatric domestic dogs (Canis familiaris) in Maasai Mara, Kenya. J Zoo Wildl Med 24:140-144

Alexander KA, Kat PW, Wayne RK, Fuller TK (1994) Serologic survey of selected canine pathogens among free-ranging jackals in Kenya. $\mathrm{J}$ Wildl Dis 30:486-491

Allsopp MT, Allsopp BA (2001) Novel Ehrlichia genotype detected in dogs in South Africa. J Clin Microbiol 39:4204-4207

Altschul SF, Gish W, Miller W, Myers EW, Lipman DJ (1990) Basic local alignment search tool. J Mol Biol 215:403-410

Anderson BE, Sumner JW, Dawson JE, Tzianabos T, Greene CR, Olson JG, Fishbein DB, Olsen-Rasmussen M, Holloway BP, George EH, Azad AF (1992a) Detection of the etiologic agent of human ehrlichiosis by polymerase chain reaction. J Clin Microbiol 30:775-780

Anderson BE, Greene CE, Jones DC, Dawson JE (1992b) Ehrlichia ewingii sp. nov., the etiologic agent of canine granulocytic ehrlichiosis. Int J Syst Bacteriol 42:299-302

Astle WL (1988) Republic of Zambia, South Luangwa National Park Map. Landscape and vegetation, Lovell Johns, Oxford

Astle WL, Webster R, Lawrance CJ (1969) Land classification for management planning in the Luangwa valley of Zambia. J Appl Ecol 6: 143-169

Averbeck GA, Bjork KE, Packer C, Herbst L (1990) Prevalence of hematozoans in lions (Panthera leo) and cheetah (Acinonyx jubatus) in Serengeti National Park and Ngorongoro Crater, Tanzania. J Wildl Dis 26:392-394

Baba K, Itamoto K, Amimoto A, Kitagawa K, Hiraoka H, Mizuno T, Sato H, Okuda M (2012) Ehrlichia canis infection in two dogs that emigrated from endemic areas. J Vet Med Sci 74:775-778

Baneth G, Sheiner A, Eyal O, Hahn S, Beaufils JP, Anug Y, Talmi-Frank D (2013) Redescription of Hepatozoon felis (Apicomplexa: Hepatozoidae) based on phylogenetic analysis, tissue and blood form morphology, and possible transplacental transmission. Parasit Vectors 6:102

Barnett SF, Brocklesby DW (1968) Some piroplasms of wild animals. Symp Zool Soc Lond 24:159-176 
Berentsen AR, Becker MS, Stockdale-Walden H, Matandiko W, McRobb R, Dunbar MR (2012) Survey of gastrointestinal parasite infection in African lion (Panthera leo), African wild dog (Lycaon pictus) and spotted hyaena (Crocuta crocuta) in the Luangwa Valley, Zambia. African Zool 47:363-368

Berentsen AR, Dunbar MR, Becker MS, M'soka J, Droge E, Sakuya NM, Matandiko W, McRobb R, Hanlon CA (2013) Rabies, canine distemper, and canine parvovirus exposure in large carnivore communities from two Zambian ecosystems. Vector Borne Zoonotic Dis 13:643-649

Bosman AM, Venter EH, Penzhorn BL (2007) Occurrence of Babesia felis and Babesia leo in various wild felid species and domestic cats in Southern Africa, based on reverse line blot analysis. Vet Parasitol 144:33-38

Bosman AM, Oosthuizen MC, Peirce MA, Venter EH, Penzhorn BL (2010) Babesia lengau sp. nov., a novel Babesia species in cheetah (Acinonyx jubatus, Schreber, 1775) populations in South Africa. J Clin Microbiol 48:2703-2708

Bosman AM, Oosthuizen MC, Venter EH, Steyl JC, Gous TA, Penzhorn BL (2013) Babesia lengau associated with cerebral and haemolytic babesiosis in two domestic cats. Parasit Vectors 6:128

Breitschwerdt EB, Kordick DL (2000) Bartonella infection in animals: carriership, reservoir potential, pathogenicity, and zoonotic potential for human infection. Clin Microbiol Rev 13:428-438

Brocklesby DW (1971) Illustrations of a Hepatozoon species in the heart of a lion. J Zool 164:525-528

Collett MG (2000) Survey of canine babesiosis in South Africa. J S Afr Vet Assoc 71:180-186

Colly LP, Nesbit JW (1992) Fatal acute babesiosis in a juvenile wild dog (Lycaon pictus). J S Afr Vet Assoc 63:36-38

Dawson JE, Stallknecht DE, Howerth EW, Warner CK, Biggie K, Davidson WR, Lockhart JM, Nettles VF, Olson JG, Childs JE (1994) Susceptibility of white-tailed deer (Odocoileus virginianus) to infection with Ehrlichia chaffeensis, the etiologic agent of human ehrlichiosis. J Clin Microbiol 32:2725-2728

Dubey JP, Bwangamoi O (1994) Microbesnoitia leoni Bwangamoi, 1989, from the African lion (Panthera leo) redetermined as a junior synonym of Hepatozoon canis (James, 1905) Wenyon, 1926. J Parasitol 80:333-334

Duncan AW, Maggi RG, Breitschwerdt EB (2007) A combined approach for the enhanced detection and isolation of Bartonella species in dog blood samples: pre-enrichment culture followed by PCR and subculture onto agar plates. J Microbiol Meth 69:273-281

East ML, Wibbelt G, Lieckfeldt D, Ludwig A, Goller K, Wilhelm K, Schares G, Thierer D, Hofer H (2008) A Hepatozoon species genetically distinct from $H$. canis infecting spotted hyenas in the Serengeti ecosystem, Tanzania. J Wildl Dis 44:45-52

Flacke G, Spiering P, Cooper D, Gunther MS, Robertson I, Palmer C, Warren K (2010) A survey of internal parasites in free-ranging African Wild Dogs (Lycaon pictus) from KwaZulu-Natal, South Africa. South African J Wildl Res 40:176-180

Gabrielli S, Kumlien S, Calderini P, Brozzi A, Iori A, Cancrini G (2010) The first report of Hepatozoon canis identified in Vulpes vulpes and ticks from Italy. Vector Borne Zoonotic Dis 10:855-859

Giadinis ND, Chochlakis D, Kritsepi-Konstantinou M, Makridaki E, Tselentis Y, Kostopoulou D, Karatzias H, Psaroulaki A (2012) Haemolytic disease in sheep attributed to a Babesia lengau-like organism. Vet Rec 170:155

Githaka N, Konnai S, Kariuki E, Kanduma E, Murata S, Ohashi K (2012) Molecular detection and characterization of potentially new Babesia and Theileria species/variants in wild felids from Kenya. Acta Trop 124:71-78

Jittapalapong S, Rungphisutthipongse O, Maruyama S, Schaefer JJ, Stich RW (2006) Detection of Hepatozoon canis in stray dogs and cats in Bangkok, Thailand. Ann N Y Acad Sci 1081:479-488
Kaminjolo JS, Nyindo MB, Sayer PD, Rurangirwa F, Johnson LW, Hird SF, Rosenbaum E, Maxie LL, Ogaa JS (1976) Identification of Ehrlichia canis in East Africa. Vet Rec 99:434-435

Kelly PJ, Matthewman LA, Mahan SM, Semu S, Peter T, Mason PR, Brouqui P, Raoult D (1994) Serological evidence for antigenic relationships between Ehrlichia canis and Cowdria ruminantium. Res Vet Sci 56:170-174

Kock MD, Meltzer, D, Burroughs, R (2006) Chemical and physical restraint of wild animals. IWVS (Africa), publishers, Greyton, South Africa. 292 pp.

Lopez-Rebollar LM, Penzhorn BL, de Waal DT, Lewis BD (1999) A possible new piroplasm in lions from the Republic of South Africa. J Wildl Dis 35:82-85

Matjila PT, Leisewitz AL, Jongejan F, Bertschinger HJ, Penzhorn BL (2008) Molecular detection of Babesia rossi and Hepatozoon sp. in African wild dogs (Lycaon pictus) in South Africa. Vet Parasitol 157:123-127

Matthewman LA, Kelly PJ, Wray K, Bryson NR, Rycroft AN, Raoult D, Mahan SM (1996) Antibodies in cat sera from southern Africa react with antigens of Ehrlichia canis. Vet Rec 138:364-365

McCully RM, Basson PA, Bigalke RD, De Vos V, Young E (1975) Observations on naturally acquired hepatozoonosis of wild carnivores and dogs in the Republic of South Africa. Onderstepoort J Vet Res 42:117-133

Molia S, Chomel BB, Kasten RW, Leutenegger CM, Steele BR, Marker L, Martenson JS, Keet DF, Bengis RG, Peterson RP, Munson L, O'Brien SJ (2004) Prevalence of Bartonella infection in wild African lions (Panthera leo) and cheetahs (Acinonyx lubatus). Vet Microbiol 100:31-41

Munson L, Terio KA, Kock R, Mlengeya T, Roelke ME, Dubovi E, Summers B, Sinclair AR, Packer C (2008) Climate extremes promote fatal co-infections during canine distemper epidemics in African lions. PLoS One 3:e2545

Nalubamba KS, Hankanga C, Mudenda NB, Masuku M (2011) The epidemiology of canine Babesia infections in Zambia. Prev Vet Med 99:240-244

Ndip LM, Ndip RN, Esemu SN, Dickmu VL, Fokam EB, Walker DH, McBride JW (2005) Ehrlichial infection in Cameroonian canines by Ehrlichia canis and Ehrlichia ewingii. Vet Microbiol 111:59-66

Neitz WO, Thomas AD (1938) Rickettsiosis in the dog. J S Afr Vet Assoc 9:166-169

Pawar RM, Poornachandar A, Srinivas P, Rao KR, Lakshmikantan U, Shivaji S (2012) Molecular characterization of Hepatozoon spp. infection in endangered Indian wild felids and canids. Vet Parasitol $186: 475-479$

Peirce MA, Laurenson MK, Gascoyne SC (1995) Hepatozoonosis in cheetahs and wild dogs in the Serengeti ecosystem. Afr J Ecol 33: 273-275

Peirce MA, Anderson MD, Penzhorn BL (2001) Piroplasmosis in the aardwolf (Proteles cristatus). Vet Rec 149:561-562

Penzhorn BL (2006) Babesiosis of wild carnivores and ungulates. Vet Parasitol 138:11-21

Penzhorn BL, Kjemtrup AM, López-Rebollar LM, Conrad PA (2001) Babesia leo n. sp. from lions in the Kruger National Park, South Africa, and its relation to other small piroplasms. J Parasitol 87:681685

Prager KC, Mazet JAK, Munson L, Cleaveland S, Donnelly CA, Dubovi EJ, Szykman Gunther M, Lines R, Mills G, Davies-Mostert HT, Weldon McNutt J, Rasmussen G, Terio K, Woodroffe R (2012) The effect of protected areas on pathogen exposure in endangered African wild dog (Lycaon pictus) populations. Biol Conserv 150: $15-22$

Pretorius AM, Kuyl JM, Isherwood DR, Birtles RJ (2004) Bartonella henselae in African lion, South Africa. Emerg Infect Dis 10:22572258 
Ramsauer S, Bay G, Meli M, Hofmann-Lehmann R, Lutz H (2007) Seroprevalence of selected infectious agents in a free-ranging, low-density lion population in the Central Kalahari Game Reserves in Botswana. Clin Vaccine Immunol 14:808-810

Rar V, Golovljova I (2011) Anaplasma, Ehrlichia, and "Candidatus Neoehrlichia" bacteria: pathogenicity, biodiversity, and molecular genetic characteristics, a review. Infect Genet Evol 11:1842-1861

Ray JC, Redford KH, Steneck RS, Berger J (2005) Large carnivores and biodiversity conservation. Island, Washington DC, USA

Roux V, Eykyn SJ, Wyllie S, Raoult D (2000) Bartonella vinsonii subsp. berkhoffii as an agent of afebrile blood culture-negative endocarditis in a human. J Clin Microbiol 38:1698-1700

Rubini AS, Dos Santos PK, Perez RR, Ribolla PE, O'Dwyer LH (2006) Molecular characterization of feline Hepatozoon species from Brazil. Vet Parasitol 137:168-171

Shock BC, Birkenheuer AJ, Patton LL, Olfenbuttel C, Beringer J, Grove DM, Peek M, Butfiloski JW, Hughes DW, Lockhart JM, Cunningham MW, Brown HM, Peterson DS, Yabsley MJ (2012) Variation in the ITS-1 and ITS-2 rRNA genomic regions of Cytauxzoon felis from bobcats and pumas in the eastern United States and comparison with sequences from domestic cats. Vet Parasitol 190:29-35

Starkey LA, Panciera RJ, Paras K, Allen KE, Reiskind MH, Reichard MV, Johnson EM, Little SE (2013) Genetic diversity of Hepatozoon spp. in coyotes from the south-central United States. J Parasitol 99: 375-378

Van den Berge L (1937) Une piroplasmide nouveau, Nuttalia alberti $\mathrm{n}$. sp. chez une hye'ne du parc national Albert (Congo Belge). Bull Soc Pathol Exot 30:271-272

Van Heerden J, Mills MG, Van Vuuren MJ, Kelly PJ, Dreyer MJ (1995) An investigation into the health status and diseases of wild dogs (Lycaon pictus) in the Kruger National Park. J S Afr Vet Assoc 66: $18-27$

Wen B, Rikihisa Y, Mott JM, Greene R, Kim HY, Zhi N, Couto GC, Unver A, Bartsch R (1997) Comparison of nested PCR with immunofluorescent-antibody assay for detection of Ehrlichia canis infection in dogs treated with doxycycline. J Clin Microbiol 35: $1852-1855$

White F (1983) The vegetation of Africa: a descriptive memoir to accompany the UNESCO/AETFAT/UNSO vegetation map of Africa. United Nations Educational Scientific and Cultural Organization, Paris, $356 \mathrm{pp}$

Woodroffe R, Prager KC, Munson L, Conrad PA, Dubovi EJ, Mazet JAK (2012) Contact with domestic dogs increases pathogen exposure in endangered African wild dogs (Lycaon pictus). PLoS ONE 7(1): e30099. doi:10.1371/journal.pone.0030099

Yabsley MJ, Greiner E, Tseng FS, Garner MM, Nordhausen RW, Ziccardi MH, Borjesson DL, Zabolotzky S (2009) Description of novel Babesia species and associated lesions from common murres (Uria aalge) from California. J Parasitol 95:1183-1188 